\title{
TINGKAT KEPATUHAN TENAGA KESEHATAN DALAM MELAKUKAN FIVE MOMENTS FOR HAND HYGIENE DI RUANG ICU BARAT RSUP SANGLAH DENPASAR TAHUN 2018
}

\author{
Firsia Sastra Putri ${ }^{1}$, Puspa Lestari ${ }^{2}$ \\ ${ }^{1}$ Program Studi S1 Keperawatan Ners, ${ }^{2}$ Sekolah Tinggi Ilmu Kesehatan Advaita Medika Tabanan \\ Korespodensi penulis: firshasastra86@gmail.com
}

\begin{abstract}
Abstrak
Latar belakang dan tujuan: Mencuci tangan merupakan rutinitas yang murah dan penting dalam prosedur pengontrolan infeksi dan merupakan metode terbaik untuk mencegah transmisi mikroorganisme. Salah satu upaya yang dijalankan di RSUP Sanglah Denpasar dalam mencegah infeksi nosokomial (HAIs) adalah dengan membudayakan kepatuhan mencuci tangan di kalangan petugas kesehatan. Adapun five moments for hand hygiene tersebut yaitu sebelum kontak dengan pasien, sebelum melaksanakan prosedur aseptik, setelah terpapar atau menyentuh cairan tubuh pasien, setelah kontak dengan pasien, dan setelah kontak dengan lingkungan sekitar pasien. Penelitian ini bertujuan untuk mengetahui tingkat kepatuhan tenaga kesehatan dalam melakukan five moments for hand hygiene di ruang ICU Barat RSUP Sanglah Denpasar Tahun 2018.

Metode: Desain penelitian ini adalah deskriptif observasional dengan rancangan cross sectional. Populasi dalam penelitian ini adalah tenaga kesehatan yang bertugas di ruang ICU Barat dengan teknik sampling yaitu purposive sampling dengan sampel sebanyak 40 responden. Data dikumpulkan dengan metode observasi.

Hasil: Hasil yang diperoleh yaitu tingkat kepatuhan tenaga kesehatan sebagian besar dalam kategori patuh yaitu sebanyak 36 orang $(90,0 \%)$.

Simpulan: Tingkat kepatuhan tenaga kesehatan sudah dalam kategori patuh dan perlu ditingkatkan lagi untuk mencapai nilai $100 \%$ dengan cara seperti adanya penyuluhan dan penilaian tentang five moments for hand hygiene.
\end{abstract}

Kata kunci: Five moments for hand hygiene, Tingkat kepatuhan

\section{Pendahuluan}

Ruang intensif merupakan tempat atau unit tersendiri di dalam rumah sakit yang merawat pasien-pasien kritis karena penyakit, trauma atau komplikasi penyakit lain yang memfokuskan diri dalam bidang life support atau organ support yang kerap membutuhkan pemantauan intensif (Noviani, T, 2010). Secara umum pasien dengan keadaan henti jantung (cardiac arrest), henti nafas (respiratory arrest), hipoksia yang tidak teratasi dengan pemberian oksigen non invasif, gagal nafas (dengan manifestasi klinis takipnea, penggunaan otot-otot pernafasan tambahan, penurunan kesadaran dengan GCS <8, saturasi oksigen menurun drastis), dan tindakan pembedahan yang menggunakan anestesi umum secara medis perlu diberikan ventilator mekanik (Sundana, 2010). Ventilator mekanik merupakan alat bantu nafas yang merupakan peralatan pada unit perawatan intensif atau Intensive Care Unit (ICU) yang digunakan pada penderita dengan indikasi gagal nafas penyakit lainnya (Sundana, 2010).

Ruang intensif merupakan tempat yang disediakan untuk merawat pasien dengan resiko tinggi yang membutuhkan perawatan tinggi di rumah sakit. Acaman bagi pasien yang berada di ruangan-ruangan resiko tinggi adalah infeksi nosokomial dan salah satu ruangan yang memiliki resiko 
tinggi yaitu ruangan Intensive Care Unit (ICU) (Ji et al, 2009). Setiap tahun diperkirakan dua juta pasien mengalami infeksi pada saat di rumah sakit, infeksi ini disebut dengan infeksi nosokomial yang diakibatkan karena ada transmisi organisme patogen yang didapat pasien dalam waktu $3 \mathrm{x}$ 24 jam pertama masa hospitalisasi (Napitupulu, 2009).

Infeksi nosokomial ini adalah salah satu penyebab utama kematian dan peningkatan morbiditas pada pasien. Mengingat asal mula infeksi yang tidak hanya didapatkan di rumah sakit, istilah infeksi nosokomial diperluas dengan istilah Healthcare Associated Infections (HAIs). Healthcare Associated Infections (HAIs) merupakan infeksi yang didapatkan pasien selama menjalani perawatan di rumah sakit. HAIs masih menjadi permasalahan diseluruh dunia. Angka kejadian HAIs di Indonesia belum diketahui jumlahnya, namun terdapat data dari beberapa Negara di dunia seperti United Kingdom yang menujukkan sekitar 300.000 pasien terkena HAIs, dan sekitar 5.000 orang diantaranya meninggal dikarenakan infeksi tersebut. HAIs menyebabkan Lenght of Say (LOS), mortalitas dan biaya perawatan meningkat. World Health Organization (WHO) menyatakan bahwa pada 7 juta orang yang terkena HAIs terdapat peningkatan biaya perawatan sebesar 80 milyar dolar Amerika.

Central of Diseases Control (CDC) mengestimasi biaya pengeluaran Rumah Sakit meningkat menjadi 208\% dikarenakan infeksi tersebut. Kerugian tersebut dapat diputus melalui upaya untuk menekan angka kejadian tersebut dengan cara menggunakan alat pelindung diri seperti sarung tangan (handscoon), masker dan lain-lain, peralatan perawatan pasien yang harus steril, pengendalian lingkungan serta tindakan terpenting dalam mengurangi HAIs yaitu dengan menjaga kebersihan tangan atau hand hygiene. Hand hygiene wajib diterapkan dan dipatuhi oleh tenaga kesehatan terlebih perawat dikarenakan $80 \%$ infeksi disebarkan melalui tangan.
Beberapa pathogen penyebab HAIs memiliki frekuensi yang cukup tinggi ditangan, seperti : Staphylococcus aureus yang merupakan penyebab utama dari infeksi luka paska operasi dan pneumonia memiliki frekuensi sekitar 10-78\% ditangan, pseudomonas spp merupakan patogen penyebab infeksi nafas bawah memiliki frekuensi sekitar 1-25\% ditangan, jamur candida sp sekitar $23-81 \%$ dan dapat bertahan selama satu jam di tangan. Hal tersebut menujukkan bahwa setiap petugas di rumah sakit harusnya melakukan kebersihan tangan sebelum melakukan berbagai aktivitas, khusunya pada five moments penting yaitu : sebelum kontak dengan pasien, sebelum melaksanakan prosedur aseptik, setelah terpapar atau menyentuh cairan tubuh pasien, setelah kontak dengan pasien, dan setelah kontak dengan lingkungan sekitar pasien (WHO, 2012).

Mencuci tangan merupakan rutinitas yang murah dan penting dalam prosedur pengontrolan infeksi dan merupakan metode terbaik untuk mencegah transmisi mikroorganisme (James, 2008). Pada umumnya mencuci tangan dilakukan hanya dengan membersihkan (menggosok) telapak tangan dan punggung tangan saja, sehingga kuman atau bakteri yang ada disela-sela jari dan ujung jari tangan masih tetap menempel ditangan, oleh karena itu mencuci tangan sesuai prosedur yang benar sangat diharapkan untuk mencegah terjadinya infeksi nosokomial (WHO, 2010). Tindakan mencuci tangan oleh perawat secara signifikan dapat menurunkan angka infeksi nosokomial. Tindakan mencuci tangan dengan menggunakan handrub dapat mengurangi infeksi nosokomial hingga 30\% dibanding dengan tidak melakukan cuci tangan (Wells, 2013). Hampir semua bakteri sementara (transient bacteria) dapat dihilangkan dengan sabun dan air, tetapi bakteri tetap (resident bacteria) akan tetap tinggal di tangan. Pencuci tangan bakterisida membuat rosedur ini lebih efektif karena menghilangkan bakteri residen (James, 2008). 
Salah satu upaya yang dijalankan di RSUP Sanglah Denpasar dalam mencegah infeksi nosokomial (HAIs) adalah dengan membudayakan kepatuhan mencuci tangan di kalangan petugas kesehatan. Pasien yang sedang dalam proses asuhan perawatan di rumah sakit dapat mengalami infeksi silang yang dapat ditularkan melalui tangan petugas kesehatan, misalnya perawat, dokter, ahli gizi, fisioterapi dan petugas kesehatan lainnya. Hal ini dapat dicegah dengan cara mencuci tangan atau yang disebut dengan five moments for hand hygiene (WHO, 2012).

Five moments for hand hygiene merupakan salah satu indikator yang disyaratkan oleh Joint Commission International (JCI) harus mencapai 100\% bagi seluruh petugas kesehatan yang memberi asuhan kepada pasien. Namun pada kenyataan sampai saat ini persentase kepatuhan petugas kesehatan terhadap five moments for hand hygiene di RSUP Sanglah Denpasar khususnya di ruang Intensive Care Unit (ICU) pada tahun 2018 mencapai 85\%. Data ini menunjukkan bahwa tingkat kepatuhan tenaga kesehatan cukup baik, namun masih belum mencapai nilai persentase $100 \%$ sesuai harapan JCI.

Berdasarkan studi pendahuluan yang dilakukan di ruang ICU Barat RSUP Sanglah Denpasar, menunjukkan bahwa jumlah perawat di ruang ICU Barat sebanyak 15 orang, jumlah dokter jaga sebanyak 2 orang, dokter visitase sebanyak 4 orang, petugas ahli gizi sebanyak 2 orang, petugas fisioterapi sebanyak 2 orang, mahasiswa praktik sebanyak 3 orang, pelatihan sebanyak 13 orang, petugas LAB sebanyak 1 orang, dan petugas radiologi sebanyak 2 orang. Dari observasi yang dilakukan di ruang ICU Barat RSUP Sanglah Denpasar didapatkan 8 orang perawat yang salah dalam melakukan five moments for hand hygiene, 1 orang dokter jaga, 3 orang dokter visitase, 2 orang petugas fisioterapi, 2 orang petugas ahli gizi, 2 orang mahasiswa praktik, 8 orang pelatihan, dan 1 orang petugas radiologi yang salah dalam melakukan five moments for hand hygiene terutama saat sebelum kontak dengan pasien dan sebelum melakukan tindakan aseptik.
Padahal yang diharapkan dari pelaksanaan five moments for hand hygiene tindakan yang dilakukan seharusnya benar dengan mencapai angka kepatuhan hand hygiene lebih dari $85 \%$. Penelitian ini bertujuan untuk mengetahui tingkat kepatuhan tenaga kesehatan dalam melakukan five moments for hand hygiene di ruang ICU Barat RSUP Sanglah Denpasar Tahun 2018.

\section{Metode Penelitian}

Penelitian ini menggunakan desain penelitian deskriptif observasional. Deskriptif observasional yaitu suatu metode penelitian yang dilakukan dengan tujuan utama untuk membuat gambaran tentang suatu keadaan secara obyektif, dengan cara melakukan observasi. Rancangan pada penelitian ini dengan pendekatan cross sectional yaitu penelitian yang dilakukan hanya satu waktu dan data yang diperoleh saat itu juga serta tidak dilakukan pengulangan pengambilan data kembali (Suyanto, 2011). Instrument yang digunakan yaitu lembar observasi.

Populasi dalam penelitian adalah subjek yang memenuhi kriteria yang telah ditetapkan (Nursalam, 2013). Populasi dalam penelitian ini adalah tenaga kesehatan yang bertugas di ruang ICU Barat diantaranya perawat, dokter jaga, dokter visite, ahli gizi, petugas lab, petugas fisioterapi, petugas radiologi, mahasiswa dan pelatihan. Total populasi yaitu sebanyak 44 orang dengan jumlah sampel yang akan diteliti yaitu sebanyak 40 orang.

Sampel adalah bagian dari jumlah dan karakteristik yang dimiliki oleh populasi (Sugiyono, 2014). Cara pengambilan sampling yang dipakai dalam penelitian ini adalah nonprobability sampling, dengan teknik sampling yaitu purposive sampling. Penelitian ini dilakukan pada tanggal $03 \mathrm{Juli}$ 2018 sampai 07 Juli 2018. Tempat penelitian ini dilaksanakan di ruang ICU Barat RSUP Sanglah Denpasar.

Teknik analisis data dalam penelitian ini menggunakan teknik analisis univariat. Analisis univariat bertujuan untuk menjelaskan atau mendeskripsikan karakteristik setiap variabel penelitian. 
Pada umumnya dalam analisis ini hanya menghasilkan distribusi frekuensi dan persentase dari tiap variabel (Notoatmodjo, 2010).

\section{Hasil dan Pembahasan}

a. Distribusi responden berdasarkan profesi dapat dilihat pada tabel 1

Tabel 1. Distribusi Frekuensi Responden Berdasarkan Profesi di Ruang ICU Barat RSUP Sanglah Denpasar

\begin{tabular}{lcc}
\hline \multicolumn{1}{c}{ Profesi } & Frekuensi (n) & Persentase (\%) \\
\hline Perawat & 13 & 32,5 \\
\hline Dokter jaga & 2 & 5,0 \\
\hline Dokter visitase & 4 & 10,0 \\
\hline Petugas ahli gizi & 1 & 2,5 \\
\hline Petugas fisioterapi & 2 & 5,0 \\
\hline Petugas radiologi & 2 & 5,0 \\
\hline Petugas LAB & 1 & 2,5 \\
\hline Pelatihan & 13 & 32,5 \\
\hline Mahasiswa praktik $\quad 2$ & 5,0 \\
\hline \multicolumn{1}{c}{ Total } & 40 & 100,0 \\
\hline
\end{tabular}

Berdasarkan data tabel 1. di atas dapat diketahui dari 40 responden yang dilihat dari segi profesi bahwa sebagian besar responden yang berprofesi sebagai perawat yaitu sebanyak 13 orang $(32,5 \%)$, dokter jaga sebanyak 2 orang $(5,0 \%)$, dokter visitase sebanyak 4 orang $(10,0 \%)$, petugas ahli gizi sebanyak 1 orang $(2,5 \%)$, petugas fisioterapi sebanyak 2 orang $(5,0 \%)$, petugas radiologi sebanyak 2 orang $(5,0 \%)$, petugas LAB sebanyak 1 orang $(2,5 \%)$, pelatihan sebanyak 13 orang $(32,5 \%)$, dan mahasiswa praktik sebanyak 2 orang $(5,0 \%)$.

b. Distribusi responden berdasarkan Hand Hygiene Sebelum Kontak dengan Pasien dapat dilihat pada tabel 2.

Tabel 2. Distribusi Frekuensi Responden Berdasarkan Hand Hygiene Sebelum Kontak dengan Pasien

\begin{tabular}{ccc}
\hline Indikasi & Frekuensi (n) & Persentase (\%) \\
\hline Benar & 30 & 75,0 \\
\hline Salah & 10 & 25,0 \\
\hline Total & 40 & 100,0 \\
\hline
\end{tabular}

Sesuai dengan tabel 1. dimana responden terdiri dari beberapa macam profesi yaitu 13 orang perawat, 2 orang dokter jaga, 4 orang dokter visitase, 1 orang petugas ahli gizi, 2 orang petugas fisioterapi, 2 orang petugas radiologi, 1 orang petugas LAB, 13 orang pelatihan dan 2 orang mahasiswa praktik, hal ini berkaitan dengan hasil pada tabel 2. yaitu didapatkan dari 13 orang perawat $(32,5 \%)$ yang melakukan tindakan hand hygiene sebelum kontak dengan pasien dengan indikasi benar yaitu berjumlah 11 orang $(27,5 \%)$ dan dengan indikasi salah yaitu berjumlah 2 orang $(5,0 \%)$. Dari 2 orang dokter jaga $(5,0 \%)$ yang melakukan tindakan hand hygiene sebelum kontak dengan pasien dengan indikasi benar yaitu berjumlah 1 orang $(2,5 \%)$ dan dengan indikasi salah yaitu berjumlah 1 orang $(2,5 \%)$. Dari 4 orang dokter visitase $(10,0 \%)$ yang melakukan tindakan hand hygiene sebelum kontak dengan pasien dengan indikasi benar yaitu berjumlah 1 orang $(2,5 \%)$ dan dengan indikasi salah yaitu berjumlah 3 orang $(7,5 \%)$. 
Dari 1 orang petugas ahli gizi $(2,5 \%)$ didapatkan melakukan tindakan hand hygiene sebelum kontak dengan pasien dengan indikasi benar. Dari 2 orang petugas fisioterapi $(5,0 \%)$ yang melakukan tindakan hand hygiene sebelum kontak dengan pasien dengan indikasi benar yaitu berjumlah 1 orang $(2,5 \%)$ dan dengan indikasi salah yaitu berjumlah 1 orang $(2,5 \%)$. Dari 2 orang petugas radiologi $(5,0 \%)$ yang melakukan tindakan hand hygiene sebelum kontak dengan pasien dengan indikasi benar yaitu berjumlah 1 orang $(2,5 \%)$ dan dengan indikasi salah yaitu berjumlah 1 orang $(2,5 \%)$. Dari 1 orang petugas LAB $(2,5 \%)$ didapatkan melakukan tindakan hand hygiene sebelum kontak dengan pasien dengan indikasi benar. Dari 13 orang pelatihan $(32,5 \%)$ pelatihan yang melakukan tindakan hand hygiene sebelum kontak dengan pasien dengan indikasi benar yaitu berjumlah 12 orang $(30,0 \%)$ dan dengan indikasi salah yaitu berjumlah 1 orang $(2,5 \%)$. Dan dari 2 orang mahasiswa praktik $(5,0 \%)$ yang melakukan tindakan hand hygiene sebelum kontak dengan pasien dengan indikasi benar yaitu berjumlah 1 orang $(2,5 \%)$ dan dengan indikasi salah yaitu berjumlah 1 orang $(2,5 \%)$.

Dari semua data tersebut memperlihatkan bahwa tindakan hand hygiene sebelum kontak dengan pasien yang dilakukan oleh tenaga kesehatan di ruang ICU Barat RSUP Sanglah Denpasar berada pada indikasi benar yaitu berjumlah 30 orang $(75,0 \%)$ dan dengan indikasi salah yaitu berjumlah 10 orang $(25,0 \%)$. Menurut WHO (2012) sebelum kontak dengan pasien tenaga kesehatan harus mencuci tangan yang bertujuan untuk mencegah risiko penularan mikroba untuk pasien. Penelitian ini didukung oleh penelitian yang dilakukan Riyani Wulandari, Siti Sholikah (2017) tentang Pengetahuan dan Penerapan Five Moments Cuci Tangan Perawat Di RSUD Sukoharjo, dari hasil penelitiannya didapatkan bahwa sebagian besar perawat sudah menerapkan hand hygiene yaitu berjumlah 17 responden dengan persentase $58,6 \%$.

c. Distribusi responden berdasarkan Hand Hygiene Sebelum Melaksanakan Prosedur Aseptik dapat dilihat pada tabel 3.

Tabel 3. Distribusi Frekuensi Responden Berdasarkan Hand Hygiene Sebelum Melaksanakan Prosedur Aseptik

\begin{tabular}{ccc}
\hline Indikasi & Frekuensi (n) & Persentase (\%) \\
\hline Benar & 35 & 87,5 \\
\hline Salah & 5 & 12,5 \\
\hline Total & 40 & 100,0 \\
\hline
\end{tabular}

Selanjutnya dari tabel 3. sesuai dengan tabel 1. yang dijelaskan di atas dimana responden terdiri dari beberapa macam profesi dalam melaksanakan tindakan hand hygiene sebelum melaksanakan prosedur aseptik. Hasil data yang didapatkan yaitu dari 13 orang perawat $(32,5 \%)$ semuanya melakukan tindakan hand hygiene sebelum melaksanakan prosedur aseptik dengan indikasi benar. Dari 2 orang dokter jaga $(5,0 \%)$ semuanya melakukan tindakan hand hygiene sebelum melaksanakan prosedur aseptik dengan indikasi benar. Dari 4 orang dokter visitase $(10,0 \%)$ yang melakukan tindakan hand hygiene sebelum melaksanakan prosedur aseptik dengan indikasi benar yaitu berjumlah 1 orang $(2,5 \%)$ dan dengan indikasi salah yaitu berjumlah 3 orang (7,5\%). Dari 1 orang petugas ahli gizi $(2,5 \%)$ didapatkan melakukan tindakan hand hygiene sebelum melaksanakan prosedur aseptik dengan indikasi benar. Dari 2 orang petugas fisioterapi $(5,0 \%)$ semuanya melakukan tindakan hand hygiene sebelum melaksanakan prosedur aseptik dengan indikasi benar. Dari 2 orang petugas radiologi $(5,0 \%)$ semuanya melakukan tindakan hand hygiene sebelum melaksanakan prosedur aseptik dengan indikasi benar. Dari 1 orang petugas LAB $(2,5 \%)$ didapatkan melakukan tindakan hand hygiene sebelum 
melaksanakan prosedur aseptik dengan indikasi benar. Dari 13 orang pelatihan $(32,5 \%)$ yang melakukan tindakan hand hygiene sebelum melaksanakan prosedur aseptik dengan indikasi benar yaitu berjumlah 12 orang $(30,0 \%)$ dan dengan indikasi salah yaitu berjumlah 1 orang $(2,5 \%)$. Dan dari 2 orang mahasiswa praktik $(5,0 \%)$ semuanya melakukan tindakan hand hygiene sebelum melaksanakan prosedur aseptik dengan indikasi benar.

Hasil dari data tersebut memperlihatkan bahwa sebagian besar tenaga kesehatan melakukan tindakan hand hygiene sebelum melaksanakan prosedur aseptik pada indikasi benar yaitu berjumlah 35 orang $(87,5 \%)$ dan dengan indikasi salah yaitu berjumlah 5 orang $(12,5 \%)$. Menurut WHO (2012) hand hygiene dilakukan untuk melindungi pasien dengan melawan infeksi kuman berbahaya, termasuk kuman yang berada di dalam tubuh pasien, selain itu bertujuan untuk memutuskan kejadian kontak dengan semua permukaan lingkungan petugas rumah sakit serta zona pasien dan segala prosedur bersih/ aseptik termasuk kontak langsung atau tidak langsung dengan membran mukus, kulit yang tidak utuh atau invasif. Tindakan ini bertujuan untuk mencegah transmisi kuman ke pasien dan dari satu bagian tubuh ke bagian tubuh lain pada pasien yang sama. Penelitian ini didukung oleh penelitian yang dilakukan Esti Suhartini, Rahayu Iskandar (2017) tentang Hubungan Sikap dengan Kepatuhan Perawat dalam Hand Hygiene Five Moment di Ruang Rawat Inap Kelas III RSUD Sleman, dari hasil penelitiannya didapatkan bahwa sebagian besar perawat memiliki sikap positif sebesar 42 perawat $(70,0 \%)$ dengan tingkat kepatuhan perawat dalam melakukan Hand Hygiene Five Moment berada dalam kategori patuh yaitu sebanyak 38 perawat dengan persentase $63,3 \%$.

d. Distribusi responden berdasarkan Hand Hygiene Setelah Terpapar atau Menyentuh Cairan Tubuh Pasien dapat dilihat pada tabel 4.

Tabel 4. Distribusi Frekuensi Responden Berdasarkan Hand Hygiene Setelah Terpapar atau Menyentuh Cairan Tubuh Pasien

\begin{tabular}{ccc}
\hline Indikasi & Frekuensi (n) & Persentase (\%) \\
\hline Benar & 40 & 100,0 \\
\hline Salah & 0 & 0 \\
\hline Total & 40 & 100,0 \\
\hline
\end{tabular}

Selanjutnya sesuai dengan tabel 1. yang telah dijelaskan sebelumnya di atas dimana responden terdiri dari 13 macam profesi yang berjumlah 40 orang dan didapatkan data yang sesuai dengan hasil dari tabel 4. mengenai tindakan hand hygiene setelah terpapar atau menyentuh cairan tubuh pasien yang memperlihatkan bahwa hand hygiene yang dilakukan oleh tenaga kesehatan berada pada indikasi benar yaitu berjumlah 40 orang $(100,0 \%)$ dan tidak ada yang berada pada indikasi salah. Menurut WHO (2012) hand hygiene dilakukan untuk melindungi petugas kesehatan dari infeksi dengan kuman pasien dan untuk melindungi lingkungan disekitar petugas kesehatan dari potensi penyebaran kuman.

e. Distribusi responden berdasarkan Hand Hygiene Setelah Kontak dengan Pasien dapat dilihat pada tabel 5 .

Tabel 5. Distribusi Frekuensi Responden Berdasarkan Hand Hygiene Setelah Kontak dengan Pasien

\begin{tabular}{ccc}
\hline Indikasi & Frekuensi (n) & Persentase (\%) \\
\hline Benar & 40 & 100,0 \\
\hline Salah & 0 & 0 \\
\hline Total & 40 & 100,0 \\
\hline
\end{tabular}


Pada tabel 5. yang berkaitan dengan tabel 1. yang telah dijelaskan sebelumnya di atas dimana responden terdiri dari 13 macam profesi yang berjumlah 40 orang, didapatkan hasil bahwa tenaga kesehatan yang melakukan tindakan hand hygiene setelah kontak dengan pasien berada pada indikasi benar yaitu berjumlah 40 orang $(100,0 \%)$ dan tidak ada yang berada pada indikasi salah. Menurut WHO (2012) hand hygiene dilakukan bertujuan untuk melindungi petugas kesehatan dari potensialnya terkena infeksi oleh kuman dari pasien dan untuk melindungi lingkungan sekitar petugas kesehatan dari kontaminasi kuman dan potensial penyebaran.

f. Distribusi responden berdasarkan Hand Hygiene Setelah Kontak dengan Lingkungan Sekitar Pasien dapat dilihat pada tabel 6 .

Tabel 6. Distribusi Frekuensi Responden Berdasarkan Hand Hygiene Setelah Kontak dengan Lingkungan Sekitar Pasien

\begin{tabular}{ccc}
\hline Indikasi & Frekuensi (n) & Persentase (\%) \\
\hline Benar & 40 & 100,0 \\
\hline Salah & 0 & 0 \\
\hline Total & 40 & 100,0 \\
\hline
\end{tabular}

Dan yang terakhir pada tabel 6. yang berkaitan dengan tabel 1 . yang telah dijelaskan sebelumnya di atas dimana responden terdiri dari 13 macam profesi yang berjumlah 40 orang, didapatkan hasil bahwa tenaga kesehatan yang melakukan tindakan hand hygiene setelah kontak dengan lingkungan sekitar pasien yang berada pada indikasi benar yaitu berjumlah 40 orang $(100,0 \%)$ dan tidak ada yang berada pada indikasi salah. Menurut WHO (2012) hand hygiene dilakukan bertujuan untuk memutus kejadian terakhir dengan benda disekitar pasien dan kontak selanjutnya dengan lingkungan disekitar petugas kesehatan. Tindakan cuci tangan setelah kontak dengan lingkungan pasien dilakukan untuk melindungi petugas kesehatan, melawan kolonial kuman pasien yang mungkin terdapat pada permukaan / benda di lingkungan sekitar pasien dan melindungi lingkungan disekitar petugas kesehatan dari potensial penyebaran kuman.

Dari ke 3 tabel di atas, penelitian tersebut didukung oleh penelitian yang dilakukan Siti Marfu'ah, Liena Sofiana (2018) yang berjudul "Analisis Tingkat Kepatuhan Hand Hygiene Perawat dalam Pencegahan Infeksi Nosokomial", dari hasil penelitiannya didapatkan bahwa sebagian besar perawat yang melakukan hand hygiene moment 3, moment 4, dan moment 5 memiliki kategori kepatuhan yang baik dengan persentase tingkat kepatuhan baik $>85 \%$.

g. Kepatuhan Tenaga Kesehatan dalam Melakukan Five Moments for Hand Hygiene di Ruang ICU Barat RSUP Sanglah Denpasar Tahun 2018

Tabel 7. Distribusi Frekuensi Tingkat Kepatuhan Tenaga Kesehatan dalam Melakukan Five Moments for Hand Hygiene di Ruang ICU Barat RSUP Sanglah Denpasar Tahun 2018

\begin{tabular}{ccc}
\hline Tingkat Kepatuhan & Frekuensi (n) & Persentase (\%) \\
\hline Patuh & 36 & 90,0 \\
\hline Cakup Patuh & 4 & 10,0 \\
\hline Kurang Patuh & 0 & 0 \\
\hline Total & 40 & 100,0
\end{tabular}


Pada tabel 7. tentang Tingkat Kepatuhan Tenaga Kesehatan dalam Melakukan Five Moments for Hand Hygiene di Ruang ICU Barat RSUP Sanglah Denpasar Tahun 2018 yang berkaitan dengan tabel 4.2. di atas didapatkan hasil penelitian menunjukkan bahwa dari jumlah 40 orang tenaga kesehatan sebagian besar memiliki tingkat kepatuhan yang tinggi dalam kategori patuh yaitu sebanyak 36 orang $(90,0 \%)$ yaitu dengan profesi perawat berjumlah 13 orang, 2 orang dokter jaga, 1 orang dokter visitase, 1 orang petugas ahli gizi, 2 orang petugas fisioterapi, 2 orang petugas radiologi, 1 orang petugas $\mathrm{LAB}, 12$ orang pelatihan dan 2 orang mahasiswa praktik, sedangkan yang memiliki tingkat kepatuhan dalam kategori cukup patuh yaitu berjumlah 4 orang $(10,0 \%)$ yaitu dengan profesi dokter visitase yang berjumlah 3 orang dan 1 orang pelatihan serta tidak ada yang memiliki tingkat kepatuhan dalam kategori kurang patuh.

Menurut Bart Smet (2014) kepatuhan adalah tingkat seseorang melaksanakan suatu cara atau berperilaku sesuai dengan apa yang disarankan atau dibebankan kepadanya. Kepatuhan merupakan modal dasar seseorang berperilaku. Perubahan sikap dan perilaku individu diawali dengan proses patuh, identifikasi dan tahap terakhir berupa internalisasi. Perubahan perilaku individu baru dapat menjadi optimal jika perubahan tersebut terjadi melalui proses internalisasi dimana perilaku yang baru itu dianggap bernilai positif bagi diri individu itu sendiri dan diintegrasikan dengan nilai-nilai lain dari hidupnya.

Hand hygiene adalah elemen inti untuk melindungi pasien terhadap infeksi nosokomial (HAIs). Hand hygiene dapat dilakukan dengan cara menggosok tangan menggunakan alkohol (alcohol-based), dimana alkohol (alcohol-based) adalah prosedur yang sederhana dan ringan yang membutuhkan waktu hanya beberapa detik (Sax H, et al., 2010). Hand hygiene merupakan istilah umum yang biasa digunakan untuk menyatakan kegiatan yang terkait dengan membersihkan tangan (WHO, 2012). Hand hygiene harus dilakukan dengan baik dan benar sebelum dan sesudah melakukan tindakan perawatan walaupun telah memakai sarung tangan dan alat pelindung lainnya. Hal ini dilakukan untuk menghilangkan atau mengurangi mikroorganisme yang ada di tangan sehingga penyebaran penyakit dapat dikurangi dan lingkungan terjaga dari infeksi.

Penerapan hand hygiene pada tenaga kesehatan yang baik didukung oleh kesadaran dari tenaga kesehatan itu sendiri dalam melindungi diri dan pasien dari bahan infeksius serta kesadaran dalam menjalankan hand hygiene sesuai dengan aturan yang benar. Kebiasaan melakukan five moments for hand hygiene di rumah sakit, merupakan perilaku mendasar dalam upaya pencegahan cross infection (infeksi silang).

Hal ini sejalan dengan penelitian dari Esti Suhartini, Rahayu Iskandar (2017) tentang Hubungan Sikap dengan Kepatuhan Perawat dalam Hand Hygiene Five Moment di Ruang Rawat Inap Kelas III RSUD Sleman, dari hasil penelitiannya didapatkan bahwa sebagian besar perawat memiliki sikap positif sebesar 42 perawat $(70,0 \%)$ dengan tingkat kepatuhan perawat dalam melakukan Hand Hygiene Five Moment berada dalam kategori patuh yaitu sebanyak 38 perawat dengan persentase $63,3 \%$.

Penelitian yang lain juga didukung oleh penelitian yang dilakukan Riyani Wulandari, Siti Sholikah (2017) tentang Pengetahuan dan Penerapan Five Moments Cuci Tangan Perawat Di RSUD Sukoharjo, dari hasil penelitiannya didapatkan bahwa sebagian besar perawat sudah menerapkan hand hygiene yaitu berjumlah 17 responden dengan persentase $58,6 \%$.

Dari hasil data di atas didapatkan tenaga kesehatan yang cukup patuh dalam melakukan hand hygiene yaitu berjumlah 4 orang $(10,0 \%)$, ini artinya tenaga kesehatan belum sepenuhnya melakukan five moments for hand hygiene yang mungkin dikarenakan adanya beberapa faktor, yaitu adanya aktivitas yang terlalu sibuk, seperti jumlah pasien yang banyak dan mementingkan pasien terlebih dahulu daripada melakukan hand hygiene, sehingga lupa untuk 
melakukan hand hygiene. Walaupun demikian ternyata didapatkan lebih banyak tenaga kesehatan yang memiliki kesadaran yang tinggi dalam melakukan five moments for hand hygiene yaitu berjumlah 36 orang $(90,0 \%)$.

Dari pembahasan tersebut dapat disimpulkan bahwa adanya beberapa faktor seperti di atas yang menyebabkan penerapan hand hygiene pada tenaga kesehatan di ruang ICU Barat memiliki kategori cukup patuh yang berjumlah 4 orang. Namun hal tersebut tidak mempengaruhi adanya penerapan tingkat kepatuhan hand hygiene dalam kategori patuh di ruangan ICU Barat dikarenakan adanya kesadaran pada tenaga kesehatan tentang pentingnya hand hygiene, selain itu sudah tersedianya fasilitas mencuci tangan yang lengkap dan mudah dijangkau oleh tenaga kesehatan sehingga pelaksanaan five moments for hand hygiene dapat dicapai dengan jumlah yang lebih banyak yaitu berjumlah 36 orang $(90,0 \%)$.

\section{Simpulan}

Adapun simpulan dari penelitian ini adalah sebagai berikut : Tingkat kepatuhan tenaga kesehatan dalam melakukan five moments for hand hygiene di ruang ICU Barat RSUP Sanglah Denpasar Tahun 2018 yaitu dari 40 orang sebagian besar tenaga kesehatan yang memiliki tingkat kepatuhan dalam kategori patuh sebanyak 36 orang $(90,0 \%)$, yang memiliki tingkat kepatuhan dalam kategori cukup patuh yaitu berjumlah 4 orang $(10,0 \%)$ dan tidak ada yang memiliki tingkat kepatuhan dalam kategori kurang patuh.

Profesi yang paling tinggi tingkat kepatuhannya adalah profesi perawat, dokter jaga, petugas ahli gizi, petugas fisioterapi, petugas radiologi, petugas $\mathrm{LAB}$, dan mahasiswa praktik, sedangkan profesi yang memiliki tingkat kepatuhan dalam kategori cukup patuh adalah profesi dokter visitase dan pelatihan. Tingkat kepatuhan tenaga kesehatan sudah dalam kategori patuh dan perlu ditingkatkan lagi untuk mencapai nilai $100 \%$ dengan cara seperti adanya penyuluhan dan penilaian tentang five moments for hand hygiene.

\section{Referensi}

James, et al. 2008. Prinsip - Prinsip Sains untuk Keperawatan. Alih Bahasa Wardhani, Penerbit Erlangga. Jakarta.

$\mathrm{Ji}$, et al. 2009. Diurnal Variability of Intraocular Pressure. Arch Soc Esp Oftalmol $82: 675-680$.

Kozier. 2010. Buku Ajar Fundamental Keperawatan (Ed. 7 vol. 2). Jakarta : EGC.

Marfu'ah Siti, Liena Sofiana. 2018. Analisis Tingkat Kepatuhan Hand Hygiene Perawat dalam Pencegahan Infeksi Nosokomial. Yogyakarta : Fakultas Kesehatan Masyarakat, Universitas Ahmad Dahlan, Yogyakarta, Indonesia.

Napitupulu, 2009. Pelayanan Publik dan Customer Statisfiction. Bandung : Alumni.

NHS. 2013. National Health Service Standard Contract. NHS England. Pp. 1-22. Available at : England.nhs.uk.

Notoatmodjo, S. 2010. Metodelogi Penelitian Kesehatan. Jakarta : Rineka Cipta.

Nursalam. 2013. Metode Penelitian dan Riset Ilmu Keperawatan. Jakarta : Salemba Medika.

Sax, H, et al. 2010. My Five Moment For Hand Hygiene : A User Centred Design Approach to Understand Train Monitor and Report Hand Hygiene. Journal of Hospital, 67, 9-21.

Smet, Bart. 2014. Psikologi Kesehatan. PT. Gramedia Widiasarna Indonesia : Jakarta.

Sugiyono, Prof Dr. 2014. Statistik untuk Penelitian. Bandung: Alfabeta.

Suhartini Esti, Rahayu Iskandar. 2017. Hubungan Sikap dengan Kepatuhan Perawat dalam Hand Hygiene Five Moment di Ruang Rawat Inap Kelas III RSUD Sleman. Yogyakarta : Stikes Jenderal Achmad Yani Yogyakarta.

Sundana, K. 2010. Mode Ventilator. Dalam : Sundana $K$, penulis. Ventilator pendekatan praktis di unit perawatan kritis. Edisi ke-1, volume 1, hal 51-57. 
Suyanto. 2011. Metodelogi dan Aplikasi Penelitian Keperawatan. Yogyakarta : Nuhamedika.

Wells, B. G, et al. 2010. Pharmacotherapy handbook 6th ed. USA : The Mc. Graw Hill Company.

WHO. 2010. WHO Guidelines on Hand Hygiene in Health Care : First Global Patient Safety Challenge Clean Care is Safer Care (diakses 04 Juli 2018). . 2012. The World Health Report 2012. http://www.who.int./whr/2012/en/inde x.html. Diakses 04 Juli 2018.

Wulandari Riyani, Siti Sholikah. 2017. Pengetahuan dan Penerapan Five Moments Cuci Tangan Perawat di Rsud Sukoharjo. Stikes Aisyiyah Surakarta. 